\title{
Editorial: Da valorização da diversidade à desejável estabilidade na investigação científica
}

Redacção

\section{(2) OpenEdition}

\section{Journals}

\section{Edição electrónica}

URL: http://journals.openedition.org/medievalista/1239

DOI: 10.4000/medievalista.1239

ISSN: 1646-740X

\section{Editora}

Instituto de Estudos Medievais - FCSH-UNL

\section{Refêrencia eletrónica}

Redacção, « Editorial: Da valorização da diversidade à desejável estabilidade na investigação científica », Medievalista [Online], 21 | 2017, posto online no dia 01 junho 2017, consultado o 23 setembro 2020. URL : http://journals.openedition.org/medievalista/1239; DOI : https://doi.org/10.4000/medievalista. 1239

\section{(c) (i) (8)}

Mediavalista está licenciado com uma Licença Creative Commons - Atribuição-NãoComercial 4.0 Internacional 
Revista ISSN 1646-740X

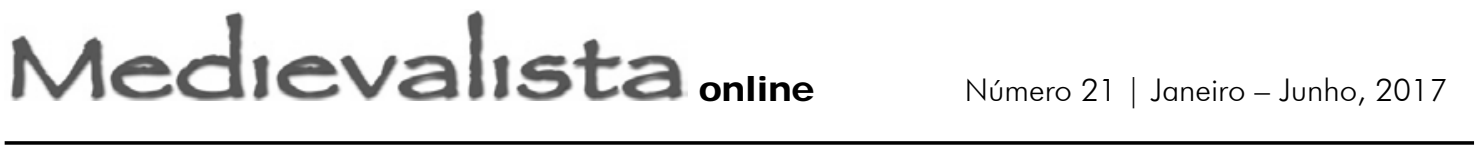

Título: Editorial: Da valorização da diversidade à desejável estabilidade na investigação científica

Autor(es) / Author(s): Redacção

Fonte: Medievalista [Em linha]. Direc. Bernardo Vasconcelos e Sousa. Lisboa: IEM.

Disponível em:

http://www2.fcsh.unl.pt/iem/medievalista/MEDIEVALISTA21/editorial2101.html

ISSN: 1646-740X 


\section{Editorial}

\section{Da valorização da diversidade à desejável estabilidade na investigação científica}

O presente número da Medievalista OnLine dá continuidade à orientação que desde o seu nascimento tem sido seguida, acolhendo trabalhos de temáticas diversificadas, de autores com posições historiográficas distintas e oriundos de países, tradições linguísticas e inserções institucionais muito variadas. Este pluralismo, que constitui uma marca genética da nossa revista, tem sido fundamental para continuar a atrair leitores e, sobretudo, autores nacionais e estrangeiros que submetem artigos seus para publicação. Isso mesmo fica de novo bem patente neste número da Medievalista.

De facto, procurando contrariar uma forte endogamia que costuma estar associada entre nós a publicações periódicas de carácter historiográfico, a grande maioria dos investigadores que se propõem publicar na Medievalista não integra o Instituto de Estudos Medievais (IEM). Mas reconhece-o, bem como à sua revista, como entidade credível para a divulgação dos resultados da respectiva investigação. É o que ocorre com os Artigos inseridos neste número, da autoria de José Alberto Morais Morán sobre o culto medieval de Santo Adrião e Santa Natália em Roma, León e Lisboa, de Carina Zubillaga sobre políticas e poéticas da memória em Castela, de Raimundo Sousa sobre monstros na representação geográfica, de Bruno Marconi da Costa sobre os mesteirais de Lisboa no século XIV e de Douglas Mota Xavier de Lima sobre o casamento do infante D. Pedro. A secção de Recensões inclui a apreciação de três livros recentes, a de Apresentação de Teses dá conta de uma dissertação de doutoramento defendida há poucos meses sobre Palmela, e, finalmente, a Varia informa sobre diversos encontros científicos de estudos medievais, organizados ou não pelo IEM, e que encontram na Medievalista um acolhimento entusiasta para a sua divulgação.

Medievalista online $\mathrm{N}^{\circ} 21$ | Janeiro - Junho 2017 @ IEM - Instituto de Estudos Medievais 2 www2.fcsh.unl.pt/iem/medievalista 
A vitalidade dos estudos medievais, de que a nossa revista é uma parte integrante, não parece, pois, estar ameaçada. Mesmo se se mantém um amargo de boca motivado por alguma desilusão sobre as condições da investigação científica entre nós, nomeadamente no que se refere às Humanidades e às Ciências Sociais. A falta de renovação das gerações de investigadores, a instabilidade e a precariedade do quadro em que continua a ser feito o trabalho científico em Portugal atingem universidades, centros de investigação e investigadores individuais. Alguns dos esperançosos anúncios públicos feitos por responsáveis pela política científica nacional, no sentido de começar a alterar a situação reinante com uma progressiva estabilização do sistema e com uma perspectiva de consolidação de equipas e de estruturas a médio e longo prazo, chocaram com a notícia do adiamento dos resultados dos concursos da Fundação para a Ciência e a Tecnologia para a atribuição de bolsas de doutoramento e pós-doutoramento. Esses resultados, que deveriam ter sido conhecidos em Outubro passado, foram protelados para o final de Fevereiro de 2017. Este adiamento, só por si, é um mau princípio, pois além de frustrar expectativas entre os candidatos e as entidades de acolhimento, relança e prolonga o clima de instabilidade e mesmo de desconfiança acerca do que será o financiamento público nesta área.

Esperemos que algo de semelhante não se verifique com o novo processo de avaliação e classificação das Unidades de Investigação, com vista à sua dotação financeira, processo esse que se prevê venha a decorrer em 2017. Que ao menos esta nova avaliação possa ser substancialmente simplificada na sua componente burocrática e, sobretudo, que não se arraste no tempo com alterações processuais nem com mudanças de critério, como ocorreu num passado recente e que importa não repetir. 


\section{COMO CITAR ESTE ARTIGO}

\section{Referência electrónica:}

“Editorial”. Medievalista [Em linha]. N. 21 (Janeiro - Junho 2017). [Consultado dd.mm.aaaa]. Disponível em

http://www2.fcsh.unl.pt/iem/medievalista/MEDIEVALISTA21/editorial2101.html ISSN 1646-740X.

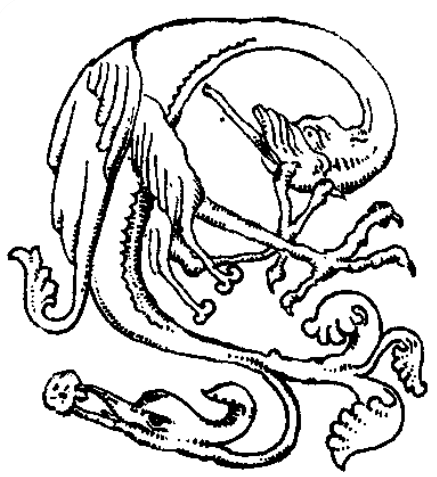

